\title{
Willow Biomass Energy Generation Efficiency and Greenhouse Gas Reduction Potential
}

\author{
Mariusz J. Stolarski ${ }^{1 *}$, Michal Krzyżaniak ${ }^{1}$, Kazimierz Warmiński², \\ Józef Tworkowski ${ }^{1}$, Stefan Szczukowski ${ }^{1}$ \\ 'Department of Plant Breeding and Seed Production, \\ ${ }^{2}$ Department of Environmental Toxicology, \\ Faculty of Environmental Management and Agriculture, \\ University of Warmia and Mazury in Olsztyn, Plac Lodzki 3, 10-724 Olsztyn, Poland
}

Received: June 24, 2015

Accepted: September 8, 2015

\begin{abstract}
This study evaluates the efficiency of energy generation from willow chips and analyses the potential to reduce GHG emissions depending on the biomass transport distance to a conversion facility. The potential amount of electrical energy ranged from $59.2 \mathrm{GJ} \cdot \mathrm{ha}^{-1}$ to $136.8 \mathrm{GJ} \cdot \mathrm{ha}^{-1}$ when produced using combustion and co-combustion, respectively. The total energy in CHP generation ranged from $295.9 \mathrm{GJ}^{\mathrm{J}} \mathrm{ha}^{-1}$ to $321.8 \mathrm{GJ} \cdot \mathrm{ha}^{-1}$ for gasification and co-combustion, respectively. It should be stressed that the largest amount of energy was produced using combustion in a heat-only boiler station.

Total GHG emissions from willow chips production and transport of $25 \mathrm{~km}$ was $73.0 \mathrm{kgCO}$ eq. $\mathrm{Mg}^{-1}$ d.m. Increasing the transport distance to 50, 100, and $200 \mathrm{~km}$ resulted in the growth of GHG emissions by $6 \%$, $17 \%$, and $39 \%$, respectively. The highest potential for reducing $\mathrm{GHG}$ emissions $\left(62.5 \mathrm{MgCO}_{2}\right.$ eq. ha $\left.{ }^{-1}\right)$ was achieved in a heat-only boiler station with the shortest transport distance. The index was $3-11 \%$ lower when energy was generated in CHP systems. The lowest potential for the reduction of GHG emissions was achieved in biomass conversion to electrical energy in the combustion process.
\end{abstract}

Keywords: biomass, willow, energy input, energy intensity, energy ratio, greenhouse gases

\section{Introduction}

Consumption of primary energy in Poland in 2013 amounted to 4,464.7 PJ. Hard coal was the most important energy carrier and its consumption accounted for $41 \%$ of the total. Crude oil accounted for $23 \%$, natural gas for $14 \%$, brown coal for $12 \%$, and other carriers for $9 \%$. The consumption structure of energy carriers has been slightly - but steadily - changing in recent years. The proportion of hard coal has been decreasing, whereas the proportion of crude oil and renewable energy sources has been increasing [1] The generation of energy from renewable sources in Poland

*e-mail: mariusz.stolarski@uwm.edu.pl increased from $5.4 \%$ to $11.7 \%$ between 2004 and 2012, which accounted for $6.7 \%$ and $7.2 \%$ of final energy consumption. Solid biomass has been the main and dominant renewable energy source in Poland for many years; it accounted for $82.4 \%$ of all the renewable energy sources in 2012 [2].

Nevertheless, hard coal and brown coal are still the dominant energy sources in professional power generation; in 2012 they accounted for $55.1 \%$ and $34.8 \%$, respectively. Natural gas accounted for 3.9\% and biomass and biogas for $6.1 \%$. However, it must be emphasized that, compared to 2007, consumption of biomass (in energy units) in Poland in 2012 increased by nearly $400 \%$, and biomass replaced approx. 7 million tons of medium-quality coal [3]. 
Coal fuels dominate in the structure of fuel consumption for heat generation in licensed heat-generation facilities. In 2013 , coal fuels accounted for $76.6 \%$, gas fuels for $7.9 \%$, fuel oil for $4.0 \%$, renewable energy sources for $6.9 \%$, and the other fuels for $4.6 \%$. However, it must be emphasised that the portion of heat generated by burning natural gas and biomass has been growing steadily by 4.0 and 4.1 percentage points, respectively. Generation of heat from biomass has increased more than two-fold since 2002 (from 11.5 PJ to 26.0 PJ) [4].

Currently, consumption of biomass in the co-combustion process dominates in Poland, which is frequently conducted in obsolete installations of low efficiency. Large power plants in Poland are interested in using biomass for co-combustion in the process of electrical energy generation mainly due to considerable financial support. It has been reported that 51 out of 55 Polish power plants are licensed to conduct co-combustion [5]. This has resulted in a high consumption of biomass ( 8.4 million tons in electrical energy generation in 2011 with 5.1 million tons used in co-combustion). It is a challenge to supply such large amounts of biomass. Wood biomass is acquired from forests, the wood industry, and as a by-product of municipal vegetation nurturing procedures.

It must be emphasised that, in the future, demand for biomass other than that from forests (i.e. mainly from agriculture and food industry) in Poland is likely to increase steadily. This is a consequence of national legislation, because the weight share of biomass from energy crops or agricultural waste and food industry (as well as grain that fails to meet the quality requirements, as well as part of other biodegradable waste except waste from forest and wood industry in the total biomass supplied to power sources with power output exceeding $5 \mathrm{MW}$ ) in which biomass is co-combusted with other fuels, should not be lower than $80 \%$ in 2015 . This percentage is projected to increase in consecutive years, reaching $85 \%$ in 2018 . However, the weight share of non-forest biomass in hybrid units and those that will burn only biomass (in systems with electric power output exceeding $20 \mathrm{MW}$ ) is to be $20 \%$ in 2015 and will increase to $50 \%$ in 2019 [6].

Perennial energy crops, including willow, should have high productivity and the biomass produced should have a high calorific value to produce considerable amounts of energy from 1 ha and a high energy-biomass production ratio. Only if this is achieved will further stages of biomass conversion to secondary energy carriers be justified as an environmentally friendly and sustainable solution. Willow biomass is used in the production of heat, electrical energy, and biofuels [7]. In Poland, willow is used to generate heat in both small household installations $[8,9]$ and in large facilities producing heat and electrical energy [10].

Willow (Salix) is a naturally-growing plant in Poland. It is generally characterized by high yield potential, easy reproduction, and it shoots after harvest cycles; therefore, it is preferred for growing as a short-rotation woody crop (SRWC). Fourteen willow cultivars are registered in the national crop register, including nine bred at the University of Warmia and Mazury in Olsztyn. Moreover, there is also a large base of 130 clones of different willow species, which provides ample opportunity for generating new, more productive cultivars. Admittedly, willow plantations currently occupy rather a symbolic area of approx. 7.5 thousand ha. It is estimated that in 2020 the area of such plantations in Poland could occupy 0.5 million ha without conflicting with food or fodder production [11]. However, today many barriers in Poland hinder the development of perennial energy crops, including policy restrictions that include lack of stable and predictable policy, and priorities regarding RES. Famers are not interested in setting up perennial plantations and biomass production, which is caused mainly by economic, market, agrotechnical, mental, and social factors.

Therefore, in the future considerable amounts of biomass should be supplied by plantations as SWRCs (willow, poplar, black locust) [12]. However, if there is still no support for biomass production in commercial SRWC plantations or no criteria of sustainability in its production, the import of considerable quantities of biomass may be necessary. This will be disadvantageous for the energy ratio and the environmental effectiveness of using biomass in energy generation. A wide range of feedstock is currently imported from more than 50 countries, which must travel thousands of kilometres and leave a visible "carbon footprint" along the way - a clear contradiction in the concept of green energy [5].

Therefore, new methods are being sought to reduce emissions to the atmosphere, mainly $\mathrm{CO}_{2}$ produced in fuel combustion processes. The most significant source of carbon dioxide emissions in Poland and other countries is electrical energy generation $[5,13,14]$. One trend is carbon dioxide capture and storage which, however, has not yet been fully applied on an industrial scale. The emission of $\mathrm{CO}_{2}$ can be reduced by applying more efficient systems of energy generation than those used to date [13]. On the other hand, using biomass for energy generation is regarded as $\mathrm{CO}_{2}$-neutral, although this is a misconception as all processes emit $\mathrm{CO}_{2}$ as fossil fuels and materials are used in the construction of bio-energy plants and in subsequent crop recovery. No system is truly $\mathrm{CO}_{2}$ neutral, but it can have substantially lower emissions compared to fossil fuel energy generation $[15,16]$. Reducing $\mathrm{CO}_{2}$ emissions depends on many factors: the choice of fuel, the biomass conversion technology selected, and the biomass transport distance to the conversion facility. Therefore, the carbon neutrality of biomass used as an energy feedstock may not always be achieved [17-20]. For example, a change in land use, cutting down forests, and biomass transport over great distances may result in higher GHG emissions compared to fossil fuels. Drastic examples include oil palm plantations set up in place of rainforests. In biodiesel production, a change in land use has resulted in an increase in emission of $\mathrm{CO}_{2}$ equivalent from 8 to 21 times compared to a fossil fuel [21].

Therefore, a field study was conducted in production and harvesting willow biomass in a commodity plantation in a three-year harvest cycle in northeastern Poland. The amount of energy spent on the production and transport 
Table 1. Energy conversion and GHG emission factors used for calculations [24].

\begin{tabular}{|c|c|c|c|c|}
\hline Item & $\begin{array}{l}\text { Energy } \\
\text { conversion } \\
\text { factor }\end{array}$ & Unit & $\begin{array}{l}\text { GHG } \\
\text { emission } \\
\text { factor }\end{array}$ & Unit \\
\hline Diesel fuel & 43.1 & $\mathrm{MJ} \cdot \mathrm{kg}^{-1}$ & 87.64 & $\mathrm{~g} \mathrm{CO}_{2}$ eq. $\cdot \mathrm{MJ}^{-1}$ \\
\hline Nitrogen fertilisers & 48.99 & $\mathrm{MJ} \cdot \mathrm{kg}^{-1} \mathrm{~N}$ & $5,880.6$ & $\mathrm{~g} \mathrm{CO}_{2}$ eq. $\cdot \mathrm{kg}^{-1} \mathrm{~N}$ \\
\hline Phosphorus fertilisers & 15.23 & $\mathrm{MJ} \cdot \mathrm{kg}^{-1} \mathrm{P}_{2} \mathrm{O}_{5}$ & $1,010.7$ & $\mathrm{~g} \mathrm{CO}_{2}$ eq. $\cdot \mathrm{kg}^{-1} \mathrm{P}_{2} \mathrm{O}_{5}$ \\
\hline Potassium fertilisers & 9.68 & $\mathrm{MJ} \cdot \mathrm{kg}^{-1} \mathrm{~K}_{2} \mathrm{O}$ & 576.1 & $\mathrm{~g} \mathrm{CO}_{2}$ eq. $\cdot \mathrm{kg}^{-1} \mathrm{~K}_{2} \mathrm{O}$ \\
\hline Other fertilisers, e.g. PRP sol & 15.23 & $\mathrm{MJ} \cdot \mathrm{kg}^{-1}$ fertiliser & $1,010.7$ & $\mathrm{~g} \mathrm{CO}_{2}$ eq. $\mathrm{kg}^{-1}$ fertiliser \\
\hline Pesticides & 268.4 & $\mathrm{MJ} \cdot \mathrm{kg}^{-1} \mathrm{~kg}$ of active substance & $10,971.3$ & $\mathrm{~g} \mathrm{CO}_{2}$ eq. $\mathrm{kg}^{-1}$ of active substance \\
\hline
\end{tabular}

of chips as well as the energy value of the yield as feedstock for energy generation was established. Subsequently, analyses of energy generation and GHG emission reduction potential were conducted. This study seeks to evaluate the efficiency of energy generation from willow chips and to assess the potential to reduce GHG emissions depending on the biomass transport distance to a conversion facility.

\section{Materials and Methods}

\section{Field Experiment}

The basis of analysis was a commercial willow plantation $\left(53^{\circ} 59^{\prime} \mathrm{N}, 21^{\circ} 05^{\prime} \mathrm{E}\right)$ owned by the University of Warmia and Mazury in Olsztyn. No top dressing was applied in the first year of willow vegetation. However, before the beginning of the second year of vegetation, mineral fertilizers were applied at: $\mathrm{N}-90 \mathrm{~kg} \cdot \mathrm{ha}^{-1}, \mathrm{P}_{2} \mathrm{O}_{5}-30$ $\mathrm{kg} \cdot \mathrm{ha}^{-1}$, and $\mathrm{K}_{2} \mathrm{O}-60 \mathrm{~kg} \cdot \mathrm{ha}^{-1}$.

After the third year willow was harvested with a Claas Jaguar 830 harvester. Chips were collected from the harvester with three units, each one consisting of a tractor and a transport trailer. Subsequently, the trailers with chips produced at the plantation were weighed and the average yield of fresh biomass in tons per ha was determined. The moisture content in the willow biomass was $50.66 \%$. Further analyses took into account the vehicle transport of chips to a biomass conversion facility, in four distance variants: 25 , 50, 100, and $200 \mathrm{~km}$. Empty trucks returning, covering the same distance, were also taken into account. The biomass transport was conducted with $80 \mathrm{~m}^{3}$ containers, which totalled $25 \mathrm{Mg}$ of fresh chips per run. The parameters of transport distance and container capacity stem from the practical aspects of biomass trade in northeastern Poland.

As an energy crop, willow is usually harvested in threeyear rotations in commodity plantations. The life cycle of a plantation ranges from 20 to 30 years, depending on habitat conditions and agrotechnical factors. Therefore, it was assumed in the study that the life cycle of a plantation is 21 years so that seven consecutive harvest cycles in three-year rotations would be possible and could be done under production conditions.

\section{Energy Intensity and Energy Ratio of the Processes}

The energy intensity and energy ratio of chips production processes were analysed based on the average fresh yield obtained from seven willow cultivars in the first threeyear harvest cycle. It must be emphasized that willow biomass yield may be diverse in successive harvest rotations. Heller et al. [22] report that subsequent harvest rotations of willow biomass will give a higher yield by up to $30-40 \%$ compared to the first harvest. Volk et al. [23] also report that the yield of four commercial clones increased by $23.0 \%$ from the first to second rotations, and by $30.8 \%$ from the first to fourth rotations. However, willow yield in consecutive harvest rotations is not always higher than in the first rotation. Production by the fourth rotation of 17 of the clones increased, while 13 decreased. Changes in the production of individual clones ranged from a decrease of $65 \%$ to an increase of $99 \%$ [23]. Furthermore, our multi-year studies have shown that the productivity of willows in consecutive rotations depends on multiple factors and, in agricultural practice, an increase in yield is indeed achieved in the second and third rotations of willow harvest. However, the yield may decrease in subsequent (4-7) harvest rotations due to an accumulation of diseases, pests, and plant loss, etc. Therefore, an increase is not always achieved in subsequent willow harvest rotations. In consequence, it was assumed in this study that mean biomass yield in subsequent harvest rotations would be similar to the first harvest rotation, which is achievable in agricultural practice.

The energy inputs used to produce the willow chips were analysed, including several energy sources: direct energy carriers (diesel fuel), exploitation of fixed assets (tractors, machines, equipment), consumption of materials (mineral fertilisers, agrochemicals, willow cuttings), and human labour. The total energy input for willow cultivation, production, and transport of chips to a biomass conversion facility was calculated based on the unit consumption of materials and the energy intensity of their production. The energy conversion and GHG emission coefficients used for calculations were based on the indexes presented by Neeft et al. [24] (Table 1). The energy input for the use of tractors $\left(125 \mathrm{MJ} \cdot \mathrm{kg}^{-1}\right)$, machines $\left(110 \mathrm{MJ} \cdot \mathrm{kg}^{-1}\right)$, and 
human labour $\left(60 \mathrm{MJ} \cdot\right.$ hour $\left.^{-1}\right)$ in the production process has been calculated with the coefficients provided in the literature plus data provided in materials published by manufacturers of tractors and machines $[25,26]$. The energy input for $1 \mathrm{~kg}$ of cuttings was $3.04 \mathrm{MJ}$ [27].

The yield energy value at the farm gate was calculated as the product of fresh biomass yield (f.m.) per ha and its lower heating value (1):

$$
Y_{e v}=Y_{b} \times Q_{i}^{r}
$$

...where: $Y_{e v}$ is biomass yield energy value at the farm gate $\left(\mathrm{GJ} \cdot \mathrm{ha}^{-1}\right), Y_{b}$ is biomass yield $\left(\mathrm{Mg} \cdot \mathrm{ha}^{-1}\right.$ f.m.), $Q_{i}^{r}$ is biomass lower heating value $\left(\mathrm{GJ} \cdot \mathrm{Mg}^{-1}\right)$.

Accumulated energy gain at the farm gate was the difference between the yield energy value and the total input for its production at the farm gate (2):

$$
E_{g f g}=Y_{e v}-E_{i f a r m}
$$

...where: $E_{g f g}$ is accumulated energy gain at the farm gate $\left(\mathrm{GJ} \cdot \mathrm{ha}^{-1}\right), Y_{e v}$ is biomass yield energy value at the farm gate $\left(\mathrm{GJ} \cdot \mathrm{ha}^{-1}\right), E_{\text {ifarm }}$ is total energy input at the farm gate $\left(\mathrm{GJ} \cdot \mathrm{ha}^{-1}\right)$.

Energy intensity at the farm gate was energy consumption per $1 \mathrm{Mg}$ of fresh or dry chips (f.m. or d.m.); it was the ratio of total energy input at the farm gate to the yield (3):

$$
E I_{f g}=E_{\text {ifarm }} / Y_{b}
$$

...where: $E I_{f g}$ is energy intensity at the farm gate $\left(\mathrm{GJ}^{\mathrm{J}} \mathrm{Mg}^{-1}\right.$ f.m. or d.m.), $E_{\text {ifarm }}$ is energy input at the farm gate $\left(\mathrm{GJ} \cdot \mathrm{ha}^{-1}\right)$, $Y_{b}$ is biomass yield (Mg.ha-1 f.m. or d.m.).

Diesel fuel consumption at the farm gate per $1 \mathrm{Mg}$ of fresh or dry willow chips was the ratio of diesel fuel consumption to willow yield (4):

$$
C_{D}{ }^{\prime}=C_{D} / Y_{b}
$$

...where: $C_{D}{ }^{\prime}$ is diesel fuel consumption at the farm gate $\left(\mathrm{kg} \cdot \mathrm{Mg}^{-1}\right.$ f.m. or d.m.), $C_{D}$ is diesel fuel consumption $\left(\mathrm{kg} \cdot \mathrm{ha}^{-1}\right), Y_{b}$ is biomass yield $\left(\mathrm{Mg} \cdot \mathrm{ha}^{-1} \mathrm{f} . \mathrm{m}\right.$. or d.m).

The energy ratio of willow chips production at the farm gate was the ratio of the yield energy value (energy output) to energy input for its production (5):

$$
E R_{f g}=Y_{e v} / E_{i f a r m}
$$

...where: $E R_{f g}$ is the energy ratio of willow chips production at the farm gate, $Y_{e v}$ is the biomass yield energy value at the farm gate $\left(\mathrm{GJ} \cdot \mathrm{ha}^{-1}\right), E_{\text {ifarm }}$ is energy input at the farm gate $\left(\mathrm{GJ} \cdot \mathrm{ha}^{-1}\right)$.

The study also included determination of energy intensity (6) and energy ratio (7) for willow chips production at a conversion facility:

$$
E I_{c f}=\left(E_{i f a r m}+E_{i \text { trans }}\right) / Y_{b}
$$

$$
E R_{c f}=Y_{e v} /\left(E_{i f a r m}+E_{i \text { trans }}\right)
$$

...where: $E I_{c f}$ is energy intensity at a conversion facility (GJ· $\mathrm{Mg}^{-1}$ f.m. or d.m.), $E_{\text {ifarm }}$ is energy input at the farm gate $\left(\mathrm{GJ} \cdot \mathrm{ha}^{-1}\right), E_{i \text { trans }}$ is energy input for chips transport to the conversion facility (GJ.ha' $\left.{ }^{-1}\right), Y_{b}$ is biomass yield $\left(\mathrm{Mg} \cdot \mathrm{ha}^{-1}\right.$ f.m. or d.m.), $E R_{c f}$ is the energy ratio of willow chips production at a conversion facility, $Y_{e v}$ is the biomass yield energy value at the farm gate $\left(\mathrm{GJ} \cdot \mathrm{ha}^{-1}\right)$.

To determine the energy ratio of energy production from willow biomass that can be sold directly to consumers as heat or electrical energy, it was assumed that biomass would be transformed into energy using co-combustion, combustion, and gasification. The efficiency of biomass conversion to combined electrical energy and heat was adopted as: for co-combustion 0.37 and 0.50 , for combustion 0.16 and 0.69 , and for gasification 0.27 and 0.53 , respectively [18]. The efficiency of producing heat in a heatonly boiler station was 0.90 . These assumptions were used to determine the amount of electrical energy and heat produced by willow biomass conversion. The amount of electrical energy that can be generated from biomass was calculated as the product of the efficiency of conversion to electrical energy and the yield energy value at the farm gate (8):

$$
E_{e}=C E_{e} \times Y_{e v}
$$

...where: $E_{e}$ is electrical energy that can be generated from biomass $\left(\mathrm{GJ} \cdot \mathrm{ha}^{-1}\right), C E_{e}$ is efficiency of conversion to electrical energy, $Y_{e v}$ is biomass yield energy value at the farm gate $\left(\mathrm{GJ} \cdot \mathrm{ha}^{-1}\right)$.

The amount of heat that can be generated from biomass has been calculated as the product of conversion-to-heat efficiency and the yield energy value at the farm gate (9):

$$
E_{h}=C E_{h} \times Y_{e v}
$$

...where: $E_{h}$ is heat energy that can be generated from biomass $\left(\mathrm{GJ} \cdot \mathrm{ha}^{-1}\right), C E_{h}$ is efficiency of conversion to heat energy, $Y_{e v}$ is biomass yield energy value at the farm gate $\left(\mathrm{GJ} \cdot \mathrm{ha}^{-1}\right)$.

The combined electrical and heat energy was calculated as (10):

$$
E_{C H P}=E_{e}+E_{h}
$$

...where: $E_{C H P}$ is combined electrical and heat energy that can be generated from biomass $\left(\mathrm{GJ} \cdot \mathrm{ha}^{-1}\right), E_{e}$ is electrical energy that can be generated from biomass $\left(\mathrm{GJ} \cdot \mathrm{ha}^{-1}\right), E_{h}$ is heat energy that can be generated from biomass $\left(\mathrm{GJ} \cdot \mathrm{ha}^{-1}\right)$.

The next stage of analysis involved determining energy input for transporting the biomass to the conversion facility (11):

$$
E_{\text {itrans }}=Y_{b} \times T \times d
$$

...where: $E_{i \text { trans }}$ is energy input for chips transport to the conversion facility $\left(\mathrm{GJ} \cdot \mathrm{ha}^{-1}\right), Y_{b}$ is biomass yield $\left(\mathrm{Mg} \cdot \mathrm{ha}^{-1}\right.$ d.m.), $T$ is energy input for biomass transport (0.00094 
$\mathrm{GJ} \cdot \mathrm{Mg}^{-1} \cdot \mathrm{km}^{-1}$ ) [24], $d$ is transport distance ( $\mathrm{km}$; empty trucks returning, covering the same distance, were also taken into account).

The energy used for the needs of conversion plants (parasitic energy losses) for co-combustion, combustion, and gasification were $7 \%, 5 \%$, and $5 \%$ of the yield energy value at farm gate, respectively [18]. The energy used for producing heat in a heat-only boiler station was $2.5 \%$. It was calculated as (12):

$$
E_{\text {iconv }}=Y_{e v} \times P E L / 100
$$

...where: $E_{i \text { conv }}$ is energy input for the conversion process $\left(\mathrm{GJ} \cdot \mathrm{ha}^{-1}\right), Y_{e v}$ is biomass yield energy value at the farm gate $\left(\mathrm{GJ} \cdot \mathrm{ha}^{-1}\right), P E L$ is parasitic energy losses (\%).

The total energy input in a simulated model of bioenergy production in a conversion facility was calculated as the total energy input for chips production at the farm gate, transport, and biomass conversion process (13).

$$
E_{\text {itotal }}=E_{i \text { farm }}+E_{\text {itrans }}+E_{i \text { conv }}
$$

...where: $E_{i \text { total }}$ is total energy input for bioenergy production in a conversion facility $\left(\mathrm{GJ} \cdot \mathrm{ha}^{-1}\right), E_{\text {ifarm }}$ is energy input for chips production at the farm gate $\left(\mathrm{GJ} \cdot \mathrm{ha}^{-1}\right), E_{i \text { trans }}$ is energy input for chips transport to the conversion facility (GJ·ha $\left.{ }^{-1}\right)$, $E_{\text {i conv }}$ is energy input for the conversion process $\left(\mathrm{GJ} \cdot \mathrm{ha}^{-1}\right)$.

The energy ratio of biomass conversion to energy using a specific conversion process was calculated as the ratio of the energy produced in the process and total energy input (14).

$$
E R_{B C}=E_{n} / E_{\text {itotal }}
$$

...where: $E R_{B C}$ is energy ratio of biomass conversion to energy using a specific conversion process, $E_{n}$ is electrical $\left(E_{e}\right)$ or heat $\left(E_{h}\right)$ or combined electrical and heat $\left(E_{C H P}\right)$ energy, which can be generated from biomass $\left(\mathrm{GJ} \cdot \mathrm{ha}^{-1}\right)$, $E_{i \text { total }}$ is total energy input for bioenergy production in a conversion facility $\left(\mathrm{GJ} \cdot \mathrm{ha}^{-1}\right)$.

\section{Analysis of GHG Emissions and Potential for Its Reduction}

Combustion of biomass from an SRWC plantation is regarded as a carbon-dioxide-neutral process because the $\mathrm{CO}_{2}$ released in the process of combustion is subsequently assimilated by plants during the next rotation [17]. Nevertheless, the processes of setting up a plantation, plant cultivation, harvesting the biomass, and its transport and conversion is accompanied by a release to the atmosphere of $\mathrm{CO}_{2}$ produced by the combustion of fossil fuels. On the other hand, only part of the biomass of SRWC is harvested, because some of it (such as rootstock, roots, and fallen leaves) is left behind. The carbon compounds in the biomass slowly decompose and become part of the soil organic matter. Therefore, it has been reported that carbon influx to the soil can be comparable to the amount of carbon released to the atmosphere during its cultivation and transport, i.e. willow biomass can be regarded as neutral for GHG emissions for the entire production cycle [18, 28-30]. According to other studies, this assumption is not necessarily true in all cases because of GHG emissions associated with the production of willow, logistical operations, and biomass transport $[31,32]$. On the other hand, the amount of carbon sequestrated in soil in the process of willow cultivation is estimated by various authors to range from 0.33 to $3.04 \mathrm{MgCO}_{2}$ eq. ha.year ${ }^{-1}$ [33-37]. The above-mentioned studies show that the total emission of greenhouse gas emitted in the process of willow cultivation, including logistics and transport, could be higher than carbon sequestration in soil.

However, using willow biomass for the production of bioenergy as a substitute for energy produced from fossil fuels has a positive GHG balance and it reduces the greenhouse effect $[18,38,39]$. Therefore, an attempt has been made to estimate the reduction of GHG emissions by replacing coal with biomass produced on 1 ha of willow cultivation in generating combined heat and electricity. It was assumed in the analysis that the total GHG emissions in the process of mining and burning the hard coal, converted to $1 \mathrm{GJ}$ of energy contained in the fuel, amounts to $0.11128 \mathrm{MgCO}_{2}$ eq. $\cdot \mathrm{GJ}^{-1}$ [24], and the average efficiency levels of hard coal conversion to electricity, electricity and heat (CHP), and heat alone in OECD countries are 41\%, $60 \%$, and $90 \%$, respectively [40]. Therefore, the GHG emission factors converted to electricity and/or heat will be: $0.27141,0.18547$, and $0.12364 \mathrm{MgCO}_{2}$ eq. $\mathrm{GJ}^{-1}$, respectively. These data are comparable with those provided for other facilities [41, 42].

The total greenhouse gas emissions associated with willow chips production, logistics, and transport were calculated using the following formulas (15-17):

$$
\begin{gathered}
E M_{w}=C_{D}{ }^{\prime \prime} \times E F_{D}+C_{N} \times E F_{N}+C_{P} \times E F_{P}+ \\
C_{K} \times E F_{K}+C_{O F} \times E F_{O F}+C_{P S} \times E F_{P S} \\
E M_{w}{ }^{\prime}=E M_{w} / Y_{b} \\
E M_{w}{ }^{\prime \prime}=E M_{w} / Y_{e v}
\end{gathered}
$$

...where: $E M_{w}, E M_{w}{ }^{\prime}$, and $E M_{w}{ }^{\prime \prime}$ are the total GHG emissions associated with willow chips production, logistics, and transport calculated per 1 ha of plantation $\left(\mathrm{kgCO}_{2}\right.$ eq. $\left.\cdot \mathrm{ha}^{-1}\right)$, $1 \mathrm{Mg}$ d.m. of biomass yield $\left(\mathrm{kgCO}_{2}\right.$ eq. $\mathrm{Mg}^{-1}$ d.m.), and $1 \mathrm{GJ}$ of biomass yield energy value $\left(\mathrm{kgCO}_{2}\right.$ eq. $\left.\mathrm{GJ}^{-1}\right)$, respectively; $C_{D}{ }^{\prime \prime}, C_{N}, C_{P}, C_{K}, C_{O F}$, and $C_{P S}$ are actual consumption of fuel $\left(\mathrm{MJ} \cdot \mathrm{ha}^{-1}\right), \mathrm{N}-, \mathrm{P}-, \mathrm{K}-$, and other fertilisers and pesticides $\left(\mathrm{kg} \cdot \mathrm{ha}^{-1}\right)$ in this experiment, respectively; $E F_{D}, E F_{N}, E F_{P}, E F_{K}, E F_{O F}$, and $E F_{P S}$ are GHG emission factors for the consumption of fuel $\left(\mathrm{kgCO}_{2}\right.$ eq. $\left.\cdot \mathrm{GJ}^{-1}\right)$, plus fertilisers and pesticides $\left(\mathrm{kgCO}_{2}\right.$ eq. $\left.\cdot \mathrm{kg}^{-1}\right)$ as reported by

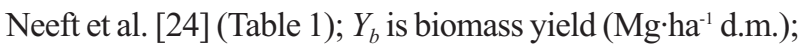
$Y_{e v}$ is biomass yield energy value at the farm gate $\left(\mathrm{GJ} \cdot \mathrm{ha}^{-1}\right)$. 
Table 2. Energy input for setting up and running a willow plantation during the first year of vegetation and its re-establishment [27].

\begin{tabular}{|c|c|c|c|c|c|c|}
\hline \multirow{2}{*}{ Operation } & Labour & Machinery & Tractors & Diesel & Materials & Total \\
\hline & \multicolumn{6}{|c|}{$\mathrm{MJ} \cdot \mathrm{ha}^{-1}$} \\
\hline Spraying (Roundup) & 18.0 & 46.4 & 11.4 & 87.8 & 386.50 & 550.07 \\
\hline Disking (2x) & 96.0 & 111.7 & 79.7 & 774.1 & - & $1,061.4$ \\
\hline Winter ploughing & 102.0 & 154.0 & 111.7 & $1,262.9$ & - & $1,630.6$ \\
\hline Fertilisation with PRP Sol & 30.0 & 9.1 & 22.8 & 175.5 & $4,569.0$ & $4,806.4$ \\
\hline Harrowing $(2 \mathrm{x})$ & 72.0 & 34.3 & 56.9 & 482.7 & - & 645.9 \\
\hline Mechanical planting of cuttings & 312.0 & 235.5 & 74.0 & 741.6 & $1,026.0$ & $2,389.1$ \\
\hline Spraying (soil-applied herbicide) & 18.0 & 46.4 & 11.4 & 87.8 & 617.3 & 780.9 \\
\hline Weeding $(2 \mathrm{x})$ & 132.0 & 74.8 & 91.9 & 605.9 & - & 904.6 \\
\hline $\begin{array}{l}\text { Spraying with a herbicide against } \\
\text { monocotyledon weeds }\end{array}$ & 18.0 & 46.4 & 11.4 & 87.8 & 33.55 & 197.12 \\
\hline Re-establishment of the plantation & 372.0 & $1,531.2$ & 446.9 & $5,051.6$ & - & $7,401.7$ \\
\hline Total & $1,170.0$ & $2,289.8$ & 918.0 & $9,357.6$ & $6,632.37$ & $20,367.8$ \\
\hline Per year of plantation use $1 / 21 \Sigma$ & 55.71 & 109.04 & 43.72 & 445.60 & 315.83 & 969.9 \\
\hline
\end{tabular}

Mean carbon sequestration in soil for willow cultivation in Poland was assumed to be $0.79 \mathrm{MgCO}_{2}$ eq. ha $^{-1} \cdot$ year $^{-1}$ (i.e. $2.37 \mathrm{MgCO}_{2}$ eq. $\mathrm{ha}^{-1}$ in a three-year cycle) [37].

The potential for GHG reduction by replacing coal with willow biomass produced at a plantation in the process of energy generation was calculated as the product of the energy produced from biomass in a conversion process, and the amount of GHG emitted in the process of energy production from hard coal. The amount of carbon sequestered in soil was then added to it and the amount of GHG emitted in the process of willow biomass production, logistics, and transport was deducted from it (18):

$$
R_{G H G}=E_{n} \times E F_{C}+S-E M_{w}
$$

...where: $R_{G H G}$ is the potential for GHG reduction by replacing coal with willow biomass $\left(\mathrm{MgCO}_{2}\right.$ eq. $\left.\mathrm{ha}^{-1}\right), E_{n}$ is electrical $\left(E_{e}\right)$ or heat $\left(E_{h}\right)$ or combined electrical and heat $\left(E_{C H P}\right)$ energy generated from biomass $\left(\mathrm{GJ} \cdot \mathrm{ha}^{-1}\right), E F_{C}$ is the GHG emission factor for the process of energy production from hard coal $\left(\mathrm{MgCO}_{2}\right.$ eq. $\left.\mathrm{GJ}^{-1}\right), S$ is the amount of carbon sequestered in soil $\left(\mathrm{MgCO}_{2} \cdot \mathrm{ha}^{-1}\right), E M_{w}$ is the amount of GHG emitted in the process of willow biomass production, logistics, and transport $\left(\mathrm{MgCO}_{2}\right.$ eq. ha $\left.{ }^{-1}\right)$.

\section{Results and Discussion}

Energy Intensity and Energy Ratios in Willow Chips Production at the Farm Gate

The energy inputs for setting up and running 1 ha of a willow coppice plantation during the first year of vegetation and its re-establishment after exploitation totalled 20,367.8

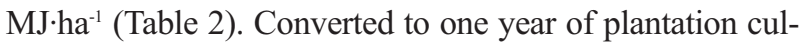
tivation (assuming that the plantation will be used for 21 years), it amounts to $969.9 \mathrm{MJ} \cdot \mathrm{ha}^{-1}$. Detailed information concerning willow farm establishment and incurred energy outlays are described by Stolarski et al. [27].

The energy input for producing willow chips in a threeyear harvest cycle, including setting up and re-establishing a plantation, NPK fertilization, and the application of a herbicide against monocotyledons, harvesting the plants, and transporting the chips, amounted to 20,088.3 $\mathrm{MJ}^{-} \mathrm{ha}^{-1}$ (Table 3).

The largest amounts of energy were consumed by harvesting the plants $(34.1 \%)$, followed by mineral fertilisation (30.9\%). The leading energy inputs involved the consumption of diesel $(48.5 \%)$, followed by materials $(32.0 \%)$ and fertilisers (approx. 30\%). In a previous study conducted by these authors, the leading energy input in willow chips production was for mineral fertilisation and fuels [43]. Moreover, Heller et al. [22] reported that the structure of energy carriers in willow biomass production was dominated by fuels (46\%), followed by fertilisation (37\%). Therefore, replacement of mineral fertilisation by sludge from local wastewater treatment stations and introducing liquid renewable fuels, such as biodiesel, to the willow biomass production process could reduce the energy input, resulting in an increase in the energy ratio of energy production by up to $40 \%[22,42]$. Nitrogen fertilisation was also a significant element of energy consumption in willow and miscanthus biomass production (17-45\%), while this value was even higher (41-64\%) in the production of biomass from annuals. In willow production, the highest energy input was required at the stage of biomass harvest and transportation [44]. 
Table 3. Energy input for producing willow chips in a three-year harvest cycle at the farm gate.

\begin{tabular}{|l|c|c|c|c|c|c|c|c|}
\hline \multirow{2}{*}{ Operation } & Labour & Machinery & Tractors & Diesel & Materials & \multicolumn{2}{c|}{ Total } & Structure \\
\cline { 2 - 9 } & \multicolumn{7}{|c|}{ MJ.ha $^{-1}$} & \multicolumn{4}{|c|}{$\%$} \\
\hline $\begin{array}{l}\text { Setting up and re-establishment of } \\
\text { plantation }\end{array}$ & 167.1 & 327.1 & 131.1 & $1,336.8$ & 947.5 & $2,909.7$ & 14.5 \\
\hline NPK fertilisation & 90.0 & 29.4 & 74.0 & 570.5 & $5,446.8$ & $6,210.7$ & 30.9 \\
\hline $\begin{array}{l}\text { Spraying with a herbicide against } \\
\text { monocotyledon weeds }\end{array}$ & 18.0 & 46.4 & 11.4 & 87.8 & 33.6 & 197.1 & 1.0 \\
\hline Harvest & 132.5 & $1,868.1$ & - & $4,852.4$ & - & $6,853.0$ & 34.1 \\
\hline Field transport & 397.5 & 235.7 & 377.18 & $2,907.48$ & - & $3,917.9$ & 19.5 \\
\hline Total & 805.2 & $2,506.7$ & 593.7 & $9,754.9$ & $6,427.8$ & $20,088.3$ & 100.0 \\
\hline Structure (\%) & 4.0 & 12.5 & 3.0 & 48.5 & 32.0 & 100.0 & \\
\hline
\end{tabular}

Table 4. Select efficiency indexes for willow chips production in a three-year harvest cycle at the farm gate.

\begin{tabular}{|l|c|c|}
\hline \multicolumn{1}{|c|}{ Item } & Unit & Value \\
\cline { 1 - 1 } Energy inputs & \multirow{2}{*}{$\mathrm{GJ}^{\prime} \cdot \mathrm{ha}^{-1}$} & 20.1 \\
\cline { 1 - 1 } Energy value of yield & & 369.9 \\
Energy gain & & 349.8 \\
\hline Diesel consumption & $\mathrm{kg} \cdot \mathrm{Mg}^{-1} \mathrm{f} . \mathrm{m}$. & 5.1 \\
\hline Diesel consumption & $\mathrm{kg} \cdot \mathrm{Mg}^{-1} \mathrm{~d} \cdot \mathrm{m}$. & 10.4 \\
\hline Energy intensity & $\mathrm{MJ} \cdot \mathrm{Mg}^{-1} \mathrm{f} \cdot \mathrm{m}$. & 455 \\
\hline Energy intensity & $\mathrm{MJ} \cdot \mathrm{Mg}^{-1} \mathrm{~d} \cdot \mathrm{m}$. & 923 \\
\hline Energy ratio & - & 18.4 \\
\hline
\end{tabular}

Since the yield of fresh willow chips averaged 44.17 $\mathrm{Mg} \cdot \mathrm{ha}^{-1}$ (while their lower heating value averaged 8.374 $\mathrm{GJ} \cdot \mathrm{Mg}^{-1}$ ) the yield energy value at the farm gate was 369.9 GJ $\cdot h^{-1}$ (Table 4). Considering the energy input for producing the yield, the energy gain in a three-year cycle amounted to $349.8 \mathrm{GJ}^{\mathrm{h}} \mathrm{ha}^{-1}$. This result was lower compared to the mean net energy from willow plantations in Sweden $\left(170 \mathrm{GJ} \cdot \mathrm{ha}^{-1} \cdot \mathrm{year}^{-1}\right)[45]$. It is also estimated that this can be increased in Sweden to over $200 \mathrm{GJ} \cdot \mathrm{ha}^{-1} \cdot$ year $^{-1}$ by using wastewater for the irrigation of a plantation of willow [46]. In a study conducted in Canada, the energy value of the yield obtained in a two-year harvest cycle in Salix viminalis with a sludge dose of $300 \mathrm{kgN} \cdot \mathrm{ha}^{-1}$ was higher than the nonfertilisation plantation (by $580 \mathrm{GJ} \cdot \mathrm{ha}^{-1}$ and $146 \mathrm{GJ} \cdot \mathrm{ha}^{-1}$, respectively) [47]. In a different study conducted in Poland on an experimental plantation of willow with a three-year harvest rotation depending on agrotechnical factors, the energy value yield at the farm gate ranged from 564 to $1,047 \mathrm{GJ}^{\mathrm{J}} \mathrm{ha}^{-1}[43,48]$. High primary net energy yields from willow (243-263 GJ·ha ${ }^{-1}$ year $^{-1}$ ) and miscanthus (224-277 GJ $\cdot h^{-1} \cdot$ year $^{-1}$ ) were obtained in Germany [44]. Tuomisto et al. [49] also confirm that miscanthus had the highest net energy production.
It was found that the consumption of diesel fuel for the production of $1 \mathrm{Mg}$ of fresh chips at the farm gate was 5.1 $\mathrm{kg}$. Low fuel consumption (3.0 1. $\mathrm{Mg}^{-1}$ of willow chips) was achieved by Goglio and Owende [50]. It was higher in studies conducted by Heller et al. [22] and by González-García et al. [51] (3.6 and 4.1 1. $\mathrm{Mg}^{-1}$, respectively). On the other hand, the consumption of fuel in the production of poplar trees ranged from 6.4 to $7.5 \mathrm{l} \cdot \mathrm{Mg}^{-1}$ [7].

The energy intensity was $455 \mathrm{MJ} \cdot \mathrm{Mg}^{-1}$ f.m. and the energy ratio in willow chips production at the farm gate was 18.4 (Table 4). The energy ratio of willow production found in other studies, depending on agrotechnical and logistical factors, varied widely - from about 12 to more than 50 $[22,29,43]$. In other studies, willow production without nitrogen application had the highest energy use efficiency (99 GJ energy output per GJ fossil energy input). Among all the energy crops tested in a study reported by Boehmel et al. [44] for this specific site, perennial lignocellulosic crops (willow and miscanthus) provide the best combination of high biomass and energy yields with high land and energy use efficiency, nitrogen fertiliser use, and environmentallyfriendly production methods.

\section{Energy Intensity and Energy Ratio in Producing Energy in a Conversion Facility}

The efficiency indexes for the production of willow chips at a conversion facility depended heavily on the distance between the plantation and the conversion facility (Table 5). The total energy input at a conversion facility ranged from 21.1 to $28.3 \mathrm{GJ}^{\mathrm{J}} \mathrm{ha}^{-1}$ when the transport distance was 25 and $200 \mathrm{~km}$, respectively. An increase in the transport distance resulted in an increase in the energy intensity of chips from 478 to $640 \mathrm{MJ} \cdot \mathrm{Mg}^{-1}$ f.m.

Furthermore, the energy ratio decreased with an increasing transport distance. When chips were transported to the shortest of the distances, the energy ratio decreased by $4.8 \%$ compared to its value at the farm gate. The transport of the chips for 50,100, and $200 \mathrm{~km}$ reduced the index by $9.2 \%, 17 \%$, and $29 \%$, respectively. A decrease in the 
Table 5. Select efficiency indexes for willow chips production in a three-year harvest cycle at a conversion facility.

\begin{tabular}{|c|c|c|}
\hline Item & Transport distance $(\mathrm{km})$ & Value \\
\hline \multirow{4}{*}{$\begin{array}{l}\text { Energy input } \\
\left(\mathrm{GJ} \cdot \mathrm{ha}^{-1}\right)\end{array}$} & 25 & 21.1 \\
\hline & 50 & 22.1 \\
\hline & 100 & 24.2 \\
\hline & 200 & 28.3 \\
\hline \multirow{4}{*}{$\begin{array}{l}\text { Energy intensity } \\
\left(\mathrm{MJ} \cdot \mathrm{Mg}^{-1} \text { f.m. }\right)\end{array}$} & 25 & 478 \\
\hline & 50 & 501 \\
\hline & 100 & 547 \\
\hline & 200 & 640 \\
\hline \multirow{4}{*}{$\begin{array}{l}\text { Energy intensity } \\
\left(\mathrm{MJ} \cdot \mathrm{Mg}^{-1} \text { d.m.) }\right.\end{array}$} & 25 & 970 \\
\hline & 50 & 1,017 \\
\hline & 100 & 1,111 \\
\hline & 200 & 1,299 \\
\hline \multirow{4}{*}{ Energy ratio } & 25 & 17.5 \\
\hline & 50 & 16.7 \\
\hline & 100 & 15.3 \\
\hline & 200 & 13.1 \\
\hline
\end{tabular}

energy ratio with increasing transport distance was also found in other studies $[50,52]$. Those authors showed that when chips were transported up to $38 \mathrm{~km}$, the energy ratio decreased by less than $8.3 \%$, and when the distance exceeded $38 \mathrm{~km}$ the decrease rate was $25.9 \%$.

Table 6 shows the yield energy value at farm gate and energy generated from biomass, which potentially can be obtained in various processes of conversion. The potential amount of electrical energy ranged from $59.2 \mathrm{GJ} \cdot \mathrm{ha}^{-1}$ to

Table 6. Yield energy value at farm gate and energy generated from biomass.

\begin{tabular}{|c|c|c|c|}
\hline $\begin{array}{l}\text { Conversion } \\
\text { process }\end{array}$ & $\begin{array}{l}\text { Type of } \\
\text { energy }\end{array}$ & $\begin{array}{c}\text { Yield } \\
\text { energy value } \\
\left(\mathrm{GJ} \cdot \mathrm{ha}^{-1}\right)\end{array}$ & $\begin{array}{l}\text { Energy generated } \\
\text { from biomass } \\
\left(\mathrm{GJ} \cdot \mathrm{ha}^{-1}\right)\end{array}$ \\
\hline \multirow{3}{*}{$\begin{array}{l}\text { Co-combustion } \\
\text { (CHP) }\end{array}$} & Electrical & \multirow{10}{*}{369.9} & 136.8 \\
\hline & Heat & & 184.9 \\
\hline & Total & & 321.8 \\
\hline \multirow{3}{*}{$\begin{array}{l}\text { Combustion } \\
\text { (CHP) }\end{array}$} & Electrical & & 59.2 \\
\hline & Heat & & 255.2 \\
\hline & Total & & 314.4 \\
\hline \multirow{3}{*}{$\begin{array}{l}\text { Gasification } \\
\text { (CHP) }\end{array}$} & Electrical & & 99.9 \\
\hline & Heat & & 196.0 \\
\hline & Total & & 295.9 \\
\hline $\begin{array}{c}\text { Combustion } \\
\text { (Heat) }\end{array}$ & Heat only & & 332.9 \\
\hline
\end{tabular}

136.8 GJ $\cdot \mathrm{ha}^{-1}$ when produced in the process of combustion and co-combustion, respectively. On the other hand, the total energy in CHP generation ranged from $295.9 \mathrm{GJ}^{-h^{-1}}$ to $321.8 \mathrm{GJ} \cdot \mathrm{ha}^{-1}$ for the processes of gasification and cocombustion, respectively. It should be stressed that the largest amount of energy was produced in the process of combustion in a heat-only boiler station (332.9 GJ.ha $\left.{ }^{-1}\right)$.

The total energy input in a conversion facility ranged from $30.4 \mathrm{GJ} \cdot \mathrm{ha}^{-1}$ with the shortest transport distance and combustion in a heat-only boiler station, to $54.2 \mathrm{GJ} \cdot \mathrm{ha}^{-1}$ with the longest distance in the process of co-combustion in a CHP station (Table 7). It increased 1.5-2.3-fold in processes of combustion and gasification to nearly threefold in co-combustion compared to its level at the farm gate. The highest energy ratio of biomass conversion to energy (9-11) was achieved in the heat generation process in a heat-only boiler station. Furthermore, the energy ratio in CHP generation was lower (by 24-38\%) depending on the process and transport distance, compared to heat generation in a heat-only boiler station. Moreover, it was lower by $28-$ $46 \%$ compared to the highest value of the index in a heatonly boiler station. It ranged from 6.3 in the process of gasification with the longest transport distance to 7.9 in combustion with the shortest transport distance. The energy ratio of biomass conversion to heat in CHP stations was also lower, ranging from 3.4 to 6.4 . The lowest energy ratio was achieved in the conversion of biomass to electrical energy only (1.3-2.9). It was several times lower than the highest index value in a heat-only boiler station. The energy ratio achieved for a heat-only boiler station was 1.7-2.1 times lower than at the farm gate. On the other hand, the ratio was 7-, 8-, and 17-fold lower for co-combustion, gasification, and combustion, respectively, compared to at the farm gate.

These ratios confirm that the best way of using biomass and its optimum use in terms of conversion efficiency was for generating heat in local heat-only boiler stations. This was followed by using biomass to generate heat and electrical energy in CHP systems. The generation of electrical energy only has proven to be the least efficient.

The energy ratio of willow biomass conversion to electricity and heat, depending on the analysed factors found in other studies conducted by these authors, ranged from 4.6 to 7.6 [43]. Furthermore, Keoleian and Volk [42] reported that the energy ratio of producing electrical energy from willow biomass by its direct combustion or gasification was higher and ranged from 10 to 13 . According to other findings, 11 units of electrical energy can be produced from willow biomass, with one unit of energy from fossil fuels consumed [22]. Meanwhile, Vande Walle et al. [18] conducted extensive cultivation of willow at low yield energy value $\left(67.3 \mathrm{GJ} \cdot\right.$ ha $^{-1} \cdot$ year $\left.^{-1}\right)$ and achieved a high energy ratio of energy production in a CHP system (7.0-8.1), depending on the process of conversion. These values should be regarded as high compared to the energy ratio of producing firstgeneration liquid fuels. For producing ethanol from grain, the index ranges $0.77-1.3[53,54]$. The ratio is better for producing second-generation fuels (ethanol) from lignocellulosic material, where the energy ratio ranges from 2.0 to 36.0 , depending on the biofuel production technology [54]. 
Table 7. Total energy input for the production of willow chips in a three-year harvest cycle, transport, and process conversion and energy ratio of biomass conversion to energy.

\begin{tabular}{|c|c|c|c|c|c|}
\hline \multirow{2}{*}{ Conversion process } & \multirow{2}{*}{$\begin{array}{l}\text { Transport distance } \\
(\mathrm{km})\end{array}$} & \multirow{2}{*}{$\begin{array}{l}\text { Total energy inputs } \\
\left(\mathrm{GJ} \cdot \mathrm{ha}^{-1}\right)\end{array}$} & \multicolumn{3}{|c|}{ Energy ratio of biomass conversion to: } \\
\hline & & & electrical energy & heat energy & CHP \\
\hline \multirow{4}{*}{$\begin{array}{l}\text { Co-combustion } \\
\text { (CHP) }\end{array}$} & 25 & 47.0 & 2.9 & 3.9 & 6.8 \\
\hline & 50 & 48.0 & 2.8 & 3.9 & 6.7 \\
\hline & 100 & 50.1 & 2.7 & 3.7 & 6.4 \\
\hline & 200 & 54.2 & 2.5 & 3.4 & 5.9 \\
\hline \multirow{4}{*}{ Combustion (CHP) } & 25 & 39.6 & 1.5 & 6.4 & 7.9 \\
\hline & 50 & 40.6 & 1.5 & 6.3 & 7.7 \\
\hline & 100 & 42.7 & 1.4 & 6.0 & 7.4 \\
\hline & 200 & 46.8 & 1.3 & 5.5 & 6.7 \\
\hline \multirow{4}{*}{ Gasification (CHP) } & 25 & 39.6 & 2.5 & 4.9 & 7.5 \\
\hline & 50 & 40.6 & 2.5 & 4.8 & 7.3 \\
\hline & 100 & 42.7 & 2.3 & 4.6 & 6.9 \\
\hline & 200 & 46.8 & 2.1 & 4.2 & 6.3 \\
\hline \multirow{4}{*}{ Combustion (Heat) } & 25 & 30.4 & - & 11.0 & - \\
\hline & 50 & 31.4 & - & 10.6 & - \\
\hline & 100 & 33.4 & - & 10.0 & - \\
\hline & 200 & 37.5 & - & 8.9 & - \\
\hline
\end{tabular}

\section{Potential for Reducing GHG Emissions by Replacing Coal with Biomass}

GHG emissions associated with growing willow, harvest, and field transport of chips (plus their loading) amounted to $1,499.8 \mathrm{kgCO}_{2}$ eq. $\cdot \mathrm{ha}^{-1}\left(68.9 \mathrm{kgCO}\right.$ eq. $\cdot \mathrm{Mg}^{-1}$ d.m. and $4.05 \mathrm{kgCO}_{2}$ eq. $\mathrm{GJ}^{-1}$ ) (Table 8 ). Transport of chips to a conversion plant $25 \mathrm{~km}$ away caused $\mathrm{GHG}$ emissions of $89.6 \mathrm{kgCO}_{2}$ eq. $\mathrm{ha}^{-1}$. Increasing the transport distance to 50,100 , and $200 \mathrm{~km}$ resulted in further increases in GHG emissions. Therefore, the total GHG emissions associated with willow chips transport for $25 \mathrm{~km}$ amounted to 1,589.4 $\mathrm{kgCO}_{2}$ eq. $\mathrm{ha}^{-1}$, which was equivalent to $73.0 \mathrm{kgCO}_{2}$ eq. $\cdot \mathrm{Mg}^{-1} \mathrm{~d} . \mathrm{m}$. and $4.30 \mathrm{kgCO} 2 \mathrm{eq} \cdot \mathrm{GJ}^{-1}$. Increasing the transport distance to 50,100 , and $200 \mathrm{~km}$ resulted in the growth of GHG emissions by $6 \%, 17 \%$, and $39 \%$, respectively.

Similar levels of GHG emissions $\left(84.0 \mathrm{kgCO}\right.$ eq. $\cdot \mathrm{Mg}^{-1}$ d.m. and $4.48 \mathrm{kgCO}_{2}$ eq. $\mathrm{GJ}^{-1}$ ) were recorded in the process of biomass production from mixed prairie grasses and an average one-way transport distance of $141 \mathrm{~km}$ [55]. On the other hand, GHG emissions for corn stover in the study referred to above were nearly twice higher than for mixed prairie grasses, despite a much shorter transport distance $(44 \mathrm{~km})$ for corn stover. The results in this experiment also indicate that GHG emissions associated with production and transport of willow chips, when converted to 1 GJ biomass, were 2.7-3.8 times lower than the GHG emissions associated with hard coal provision. Giuntoli et al. [56] report that the average European (EU coal mix) emission factor for the supply of hard coal is $16.2 \mathrm{kgCO}_{2}$ eq. $\cdot \mathrm{GJ}^{-1}$.

Fertilisation and pesticides were responsible for the largest portion (35.1-41.1\%) of the GHG emissions when willow chips are transported for $25 \mathrm{~km}, 50 \mathrm{~km}$, and $100 \mathrm{~km}$. However, when chips were transported for $200 \mathrm{~km}$, transport was responsible for the largest portion (32.3\%) of GHG emissions, followed by fertilisation and pesticides, responsible for $29.5 \%$ of the emissions (Fig. 1). The contribution of transport to GHG emissions decreased considerably to $19.3 \%, 10.7 \%$, and $5.6 \%$ with the transport distance decreasing to $100 \mathrm{~km}, 50 \mathrm{~km}$, and $25 \mathrm{~km}$, respectively. The crop harvest was responsible for a considerable portion of the GHG emissions. It was responsible for the second largest portion $-26.8 \%$ - in transporting willow chips for $25 \mathrm{~km}$, and the third largest (19.2\%) when chips were transported for $200 \mathrm{~km}$.

The outcome of analysis of the potential for reduction of GHG emissions by replacing hard coal with willow biomass in energy production depended on the biomass yield energy value. A simulation showed that the highest potential for reduction of GHG emissions $\left(62.5 \mathrm{MgCO}_{2}\right.$ eq. $\left.\cdot \mathrm{ha}^{-1}\right)$ was achieved in the production of heat in a heat-only boiler station with the shortest transport distance (Table 9). The index was 3-11\% lower when heat and electrical energy were generated in CHP systems. Furthermore, the potential for reducing GHG emissions in biomass conversion to 
Table 8. GHG emissions associated with willow chips production in a three-year cycle and delivery to a conversion facility.

\begin{tabular}{|c|c|c|c|}
\hline \multirow{2}{*}{ Item } & \multicolumn{3}{|c|}{ GHG emissions } \\
\hline & $\left(\mathrm{kgCO}_{2}\right.$ eq $\cdot$ ha $\left.^{-1}\right)$ & $\left(\mathrm{kgCO}_{2}\right.$ eq. $\cdot \mathrm{M}^{\mathrm{g}-1}$ d.m. $)$ & $\left(\mathrm{kgCO}_{2}\right.$ eq. $\left.\cdot \mathrm{GJ}^{-1}\right)$ \\
\hline Establishment and re-establishment of the plantation & 166.5 & 7.7 & 0.45 \\
\hline Spraying (Roundup) & 3.4 & 0.2 & 0.01 \\
\hline Disking $(2 \mathrm{x})$ & 9.7 & 0.4 & 0.03 \\
\hline Winter ploughing & 15.8 & 0.7 & 0.04 \\
\hline Fertilisation with PRP Sol & 45.5 & 2.1 & 0.12 \\
\hline Harrowing $(2 \mathrm{x})$ & 6.0 & 0.3 & 0.02 \\
\hline Mechanical planting of cuttings & 9.3 & 0.4 & 0.03 \\
\hline Spraying (soil-applied herbicide) & 4.7 & 0.2 & 0.01 \\
\hline Weeding $(2 \mathrm{x})$ & 7.6 & 0.3 & 0.02 \\
\hline Spraying (herbicide against monocotyledon weeds) & 1.3 & 0.1 & 0.00 \\
\hline Re-establishment of the plantation & 63.2 & 2.9 & 0.17 \\
\hline Fertilisers, pesticides & 653.2 & 30.0 & 1.77 \\
\hline NPK fertilisation & 644.1 & 29.6 & 1.74 \\
\hline Spraying (herbicide against monocotyledon weeds) & 9.1 & 0.4 & 0.02 \\
\hline Harvest & 425.3 & 19.5 & 1.15 \\
\hline Field transport and loading & 254.8 & 11.7 & 0.69 \\
\hline Total on the field & $1,499.8$ & 68.9 & 4.05 \\
\hline Transportation $25 \mathrm{~km}$ & 89.6 & 4.1 & 0.24 \\
\hline Transportation $50 \mathrm{~km}$ & 179.3 & 8.2 & 0.48 \\
\hline Transportation $100 \mathrm{~km}$ & 358.6 & 16.5 & 0.97 \\
\hline Transportation $200 \mathrm{~km}$ & 717.1 & 33.0 & 1.94 \\
\hline Total $25 \mathrm{~km}$ & $1,589.4$ & 73.0 & 4.30 \\
\hline Total $50 \mathrm{~km}$ & $1,679.1$ & 77.2 & 4.54 \\
\hline Total $100 \mathrm{~km}$ & $1,858.4$ & 85.4 & 5.02 \\
\hline Total $200 \mathrm{~km}$ & $2,216.9$ & 101.9 & 5.99 \\
\hline
\end{tabular}

heat in CHP plants was lower by $48-63 \%$ compared to its highest value. On the other hand, the lowest potential for the reduction of GHG emissions was achieved in biomass conversion to electrical energy in the combustion process. An increase in transport distance resulted in a decrease in the potential for reduction of GHG in each of the analysed technologies of biomass conversion.

Apart from its value per 1 ha of a plantation, the potential to reduce GHG emission depends on the plantation area. In order to illustrate the capacity for the reduction of GHG emissions, it was assumed that the area of willow plantations for energy production in a region have an area of 10,000 ha. Assuming a transport distance of $25 \mathrm{~km}$ from a conversion point, it can be calculated that it is an area of 196,250 ha. The area of the agricultural land in Poland amounts to 18.7 million ha, which accounts for approx.
$60 \%$ of the country area [57]. Therefore, the area of agricultural land in a circle with a radius of $25 \mathrm{~km}$ is 117,750 ha. In consequence, willow plantations with an area of 10,000 ha would account for about $8.5 \%$ of the area. With longer transport distances of $50 \mathrm{~km}, 100 \mathrm{~km}$, and $200 \mathrm{~km}$, such plantations would account for $2.1 \%, 0.5 \%$, and $0.1 \%$ of agricultural land within a specific area, respectively. Obviously, the actual proportion of willow plantations in the structure of agricultural land of an area will depend on the specificity of a region, that is, geographic, climatic, and soil conditions, location of biomass conversion plants, and economy of biomass production to farmers.

The potential reduction of GHG in the production of heat in a heat-only boiler station and with biomass transport for $25 \mathrm{~km}$ in such a variant would be up to 208,000 tons per year. In CHP, depending on the conversion technology and 
Table 9. Potential for reduction of GHG emissions $\left(\mathrm{MgCO}_{2}\right.$ eq. ha $\left.{ }^{-1}\right)$ through replacement of hard coal with willow biomass for energy production (in a three-year harvest cycle).

\begin{tabular}{|c|c|c|c|c|}
\hline Conversion process & $\begin{array}{c}\text { Transport distance } \\
(\mathrm{km})\end{array}$ & $\begin{array}{l}\text { Biomass conversion } \\
\text { to electricity }\end{array}$ & $\begin{array}{c}\text { Biomass conversion } \\
\text { to heat }\end{array}$ & $\begin{array}{l}\text { Biomass conversion } \\
\text { to electricity and heat }\end{array}$ \\
\hline \multirow{4}{*}{ Co-combustion (CHP) } & 25 & 37.9 & 23.6 & 60.5 \\
\hline & 50 & 37.8 & 23.6 & 60.4 \\
\hline & 100 & 37.7 & 23.4 & 60.2 \\
\hline & 200 & 37.3 & 23.0 & 59.8 \\
\hline \multirow{4}{*}{ Combustion (CHP) } & 25 & 16.8 & 32.3 & 59.1 \\
\hline & 50 & 16.8 & 32.2 & 59.0 \\
\hline & 100 & 16.6 & 32.1 & 58.8 \\
\hline & 200 & 16.2 & 31.7 & 58.5 \\
\hline \multirow{4}{*}{ Gasification (CHP) } & 25 & 27.9 & 25.0 & 55.7 \\
\hline & 50 & 27.8 & 24.9 & 55.6 \\
\hline & 100 & 27.6 & 24.7 & 55.4 \\
\hline & 200 & 27.3 & 24.4 & 55.0 \\
\hline \multirow{4}{*}{ Combustion (Heat) } & 25 & - & 62.5 & - \\
\hline & 50 & - & 62.4 & - \\
\hline & 100 & - & 62.2 & - \\
\hline & 200 & - & 61.9 & - \\
\hline
\end{tabular}

the transport distance, the potential for GHG reduction was lower - from 183,000 to 201,000 tons per year. The value of the index for generating electrical energy only was the lowest in the process of combustion and lay within an interval of from 54,000 to 56,000 tons per year. Therefore, it is the best option in terms of the potential to reduce $\mathrm{CO}_{2}$ emissions to use willow chips to produce heat in a heat-only boiler station. However, environmental benefits can also be gained by using biomass as a solid fuel in other energy generation processes. For example, according to Heller et al. [58], the addition of $10 \%$ of biomass in the process of its co-combustion resulted in an increase in energy generation efficiency by $8.9 \%$ and reduced its contribution to the greenhouse effect by $7-10 \%$ compared to coal.

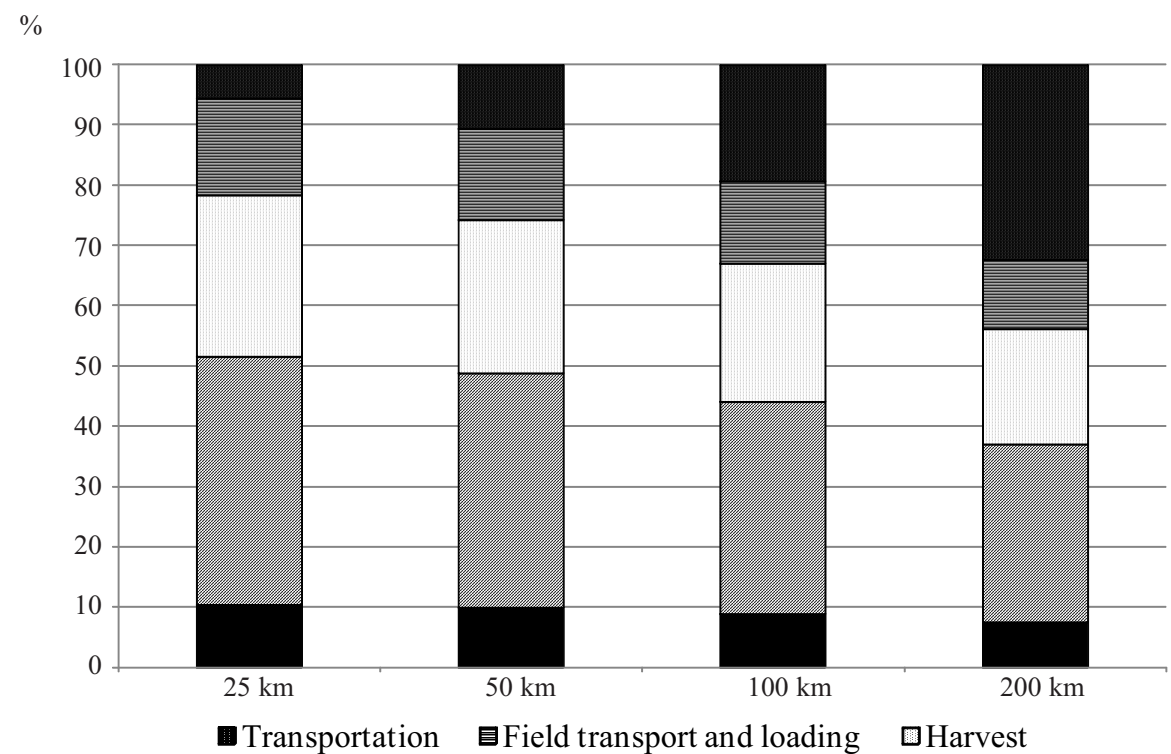

Fertilisers, pesticides

Establishment and re-establishment of the plantation

Fig. 1. Structure of GHG emissions associated with willow chips production in a three-year cycle and delivery to a conversion facility. 


\section{Conclusions}

This study has shown that the production of energy from willow biomass can be beneficial in terms of energy efficiency, which can contribute to reduced fossil fuel consumption. In analysing the energy ratio of willow chips production, the generation of heat in a heat-only boiler station proved to be the best option. The total accumulated energy input at a conversion facility rose with increasing distances of chips transport from 1.5-2.3-fold for gasification and combustion to nearly 3 -fold in the process of co-combustion compared to their values at the farm gate. The highest energy ratio (9-11) was achieved in the heat generation process in a heat-only boiler station. Furthermore, the values of this index in CHP generation were lower by $24-38 \%$ and in the conversion of biomass to electrical energy they were several times lower compared to heat generation in a heat-only boiler station.

Total GHG emissions from production of willow chips and their transport for $25 \mathrm{~km}$ amounted to $73.0 \mathrm{kgCO}_{2}$ eq. $\mathrm{Mg}^{-1} \mathrm{~d} . \mathrm{m}$. Increasing the transport distance to $50 \mathrm{~km}$, $100 \mathrm{~km}$, and $200 \mathrm{~km}$ resulted in a growth of GHG emissions by $6 \%, 17 \%$, and $39 \%$, respectively. The contribution of fertilisers and pesticides dominated in the structure of GHG emissions when willow chips were transported for $25 \mathrm{~km}, 50 \mathrm{~km}$, and $100 \mathrm{~km}$; when the transport distance increased to $200 \mathrm{~km}$, contribution of transport was the largest. The highest potential for the reduction of GHG emissions $\left(62.5 \mathrm{MgCO}_{2}\right.$ eq. $\left.\mathrm{ha}^{-1}\right)$ was achieved in the production of heat in a heat-only boiler station with the shortest transport distance. It has been shown in a simulation for this variant that when willow is produced for energy feedstock in an area of 10,000 ha, the GHG could be reduced by up to 208,000 tons per year.

\section{Acknowledgements}

This research received funding from the European Union Seventh Framework Programme (FP7/2007-2013) under grant agreement No. 241718 EuroBioRef.

\section{References}

1. ENERGY statistics in 2012 and 2013. Central Statistical Office, Warsaw, pp. 298, 2014.

2. ENERGY from renewable sources in 2013. Central Statistical Office, Warsaw, pp. 72, 2014 [In Polish].

3. GRUDZIŃSKI Z., STALA-SZLUGAJ K. The role of hard coal in the Polish fuel and energy balance. Polityka Energetyczna - Energy Policy Journal. 17, (3), 49, 2014 [In Polish].

4. BUŃCZYK A. Heat Generation in Figures. Energy Regulatory Office, Warsaw, pp. 110, 2014 [In Polish].

5. WIŚNIEWSKI G., MICHAŁOWSKA-KNAP K., ARCIPOWSKA A. On the unsustainable use of renewable energy resources in Poland and the pathology of the RES support system. Proposals for changes in the approach to the promotion of renewable energy sources and trends in bio- mass resources. Warszawa: Instytut Energetyki Odnawialnej, 2012 [In Polish].

6. REGULATION OF THE MINISTER OF ECONOMY of 18 October 2012 on detailed scope of obligations in obtaining certificates of origin and submitting them for cancellation, payment of a substitution fee, purchase of electricity and heat from renewable energy sources, as well as the obligation to confirm the data on the amount of electricity produced from a renewable energy source, Journal of Laws, item 1229, 2012 [In Polish].

7. WANG Z., DUNN J.B., WANG M.Q. GREET Model Short Rotation Woody Crops (SRWC) Parameter Development. Center for Transportation Research. Argonne National Laboratory, 2012.

8. STOLARSKI M.J., KRZYŻANIAK M., WARMIŃSKI K., ŚNIEG M. Energy, economic and environmental assessment of heating a family house with biomass. Energy Buildings. 66, 395, 2013.

9. STOLARSKI M., KRZYZANIAK M., GRABAN Ł. Evaluation of energy-related and economic aspects of heating a family house with dendromass in the north-east of Poland. Energy Buildings. 43, 433, 2011.

10. OWOC D., WALCZYK J. Use of energy willow for the production of energy in the Podkarpackie province. Acta Scientiarum Polonorum-Silvarum Colendarum Ratio et Industria Lignaria. 12, 37, 2013.

11. BUDZYŃSKI W., SZCZUKOWSKI S., TWORKOWSKI J. Selected issues regarding energy crops production. 1st Congress of Agricultural Sciences. The future of agriculture and food production sector and rural areas. Puławy, 76-89, 2009 [In Polish].

12. STOLARSKI M.J., KRZYŻANIAK M., SZCZUKOWSKI S., TWORKOWSKI J., BIENIEK A. Short rotation woody crops grown on marginal soil for biomass energy. Pol. J. Environ. Stud., 23, (5), 1727, 2014.

13. STAŃCZYK K., BIENIECKI M. Possibilities of $\mathrm{CO}_{2}$ reduction and its influence on effectiveness and cost of energy generation from coal. Górnictwo i Geoinżynieria. 31, 575, 2007.

14. GOMES J., NASCIMENTO J., RODRIGUES H. Estimating local greenhouse gas emissions - A case study on a Portuguese municipality. International Journal of Greenhouse Gas Control. 2, 130, 2008.

15. JOHNSON E. Goodbye to carbon neutral: Getting biomass footprints right. Environ. Impact Asses. 29, 165, 2009.

16. AGOSTINI A., GIUNTOLI J., BOULAMANTI A. Carbon Accounting of Forest Bioenergy: Conclusions and Recommendations from a Critical Literature Review. Report EUR 25354 EN. JRC Technical ReportsPublications. Luxembourg: 2013.

17. PROE M.F., GRIFFITHS J.H., CRAIG J. Effects of spacing, species and coppicing on leaf area, light interception and photosynthesis in short rotation forestry. Biomass Bioenerg. 23, 315, 2002.

18. VANDE WALLE I., VAN CAMP N., VAN DE CASTEELE L., VERHEYEN K., LEMEUR R. Short-rotation forestry of birch, maple, poplar and willow in Flanders (Belgium) II. Energy production and $\mathrm{CO}_{2}$ emission reduction potential. Biomass Bioenerg. 31, 276, 2007.

19. JÄPPINEN E., KORPINEN O.J., LAITILA J., RANTA T. Greenhouse gas emissions of forest bioenergy supply and utilization in Finland. Renew. Sust. Energ. Rev. 29, 369, 2014.

20. FELTEN D., FRÖBA N., FRIES J., EMMERLING C. Energy balances and greenhouse gas-mitigation potentials 
of bioenergy cropping systems (Miscanthus, rapeseed, and maize) based on farming conditions in Western Germany. Renew. Energ. 55, 160, 2013.

21. BEER T., GRANT T., CAMBELL P.K. The greenhouse and air quality emissions of biodiesel blends in Australia. CSIRO. Australia, pp. 115, 2007.

22. HELLER M.C., KEOLEIAN G.A., VOLK T.A. Life cycle assessment of a willow bioenergy cropping system. Biomass Bioenerg. 25, 147, 2003.

23. VOLK T.A., ABRAHAMSON L.P., CAMERON K.D., CASTELLANO P., CORBIN T., FABIO E., JOHNSON G. Yields of willow biomass crops across a range of sites in North America. Aspects of Applied Biology. 112, 67, 2011.

24. NEEFT J., GAGNEPAIN B., BACOVSKY D., LAURANSON R., GEORGAKOPOULOS K., FEHRENBACK H. Harmonized calculations of biofuel greenhouse gas emissions in Europe, in, Netherlands. http://www.biograce.net/ content/ghgcalculationtools/recognisedtool/ (Accessed 28. 11. 2014).

25. SZEPTYCKI A., WÓJCICKI Z. Technical development and energy inputs in agriculture till 2020. Warszawa: IBMER, 2003 [In Polish].

26. IBMER. Catalog of agricultural machines. Warszawa: IBMER, 2007 (CD-rom)

27. STOLARSKI M.J., KRZYŻANIAK M., TWORKOWSKI J., SZCZUKOWSKI S., GOŁASZEWSKI J. Energy intensity and energy ratio in producing willow chips as feedstock for an integrated biorefinery. Biosystems Engineering. 123, 19, 2014.

28. SÁEZ R.M., LINARES P., LEAL J. Assessment of the externalities of biomass energy, and a comparison of its full costs with coal. Biomass Bioenerg. 14, 469, 1998.

29. MATTHEWS R.W. Modelling of energy and carbon budgets of wood fuel coppice systems. Biomass Bioenerg. 21, 1, 2001.

30. LETTENS S., MUYS B., CEULEMANS R., MOONS E., GARCIA J., COPPIN P. Energy budget and greenhouse gas balance evaluation of sustainable coppice systems for electricity production. Biomass Bioenerg. 24, 179, 2009.

31. CLAIR S.S., HILLIER J., SMITH P. Estimating the pre-harvest greenhouse gas costs of energy crop production. Biomass Bioenerg. 32, 442, 2008.

32. BÖRJESSON P. Life Cycle Assessment of Willow Production. Lund; Institutionen för teknik och samhälle. Report No. 60, Lunds Tekniska Högskola, 2006.

33. SMITH P. Carbon sequestration in croplands: The potential in Europe and the global context. Eur. J. Agron. 20, 229, 2004.

34. KING J.A., BRADLEY R.I., HARRISON R., CARTER A.D. Carbon sequestration and saving potential associated with changes to the management of agricultural soils in England. Soil Use Manage. 20, 394, 2004

35. BORZECKA-WALKER M., FABER A., BOREK R. Evaluation of carbon sequestration in energetic crops (Miscanthus and coppice willow). Int. Agrophys. 22, 185, 2008.

36. BRANDÃO M., MILÀICANALS L., CLIFT R. Soil organic carbon changes in the cultivation of energy crops: Implications for GHG balances and soil quality for use in LCA. Biomass Bioenerg. 35, 2323, 2011.

37. BORZECKA-WALKER M., FABER A., MIZAK K., PUDEŁKO R., SYP A. Soil Carbon Sequestration Under Bioenergy Crops in Poland. In: Burcu Özkaraova Güngör E, editor. Principles, Application and Assessment in Soil Science, Rijeka: In Tech, pp. 151-66, 2011.
38. [SCHWAIGER H., SCHLAMADINGER B. The potential of fuelwood to reduce greenhouse gas emissions in Europe. Biomass Bioenerg. 15, 369, 1998.

39. ZAH R., BÖNI H., GAUCH M., HISCHIER R., LEHMANN M., WÄGER P. Life Cycle Assessment of Energy Products: Environmental Impact Assessment of Biofuels. Zurich: Bundesamt für Energie, Bundesamt für Umwelt, Bundesamt für Landwirtschaft, 2007.

40. INTERNATIONAL ENERGY AGENCY. $\mathrm{CO}_{2}$ emissions from fuel combustion. Highlights (2013 Edition). Paris: International Energy Agency, 2013.

41. MATTHEWS R., ROBERTSON K. Answers to ten frequently asked questions about bioenergy, carbon sinks and their role in global climate change. http://www.biomassenergycentre.org.uk/pls/portal/docs/PAGE/RESOURCES/RE F_LIB_RES/PUBLICATIONS/IEA\%20BIOENERGY\%20TEN\%20FAQ.PDF (Accessed 12.12.2014).

42. KEOLEIAN G.A., VOLK T.A. Renewable energy from willow biomass crops: Life cycle energy, environmental and economic performance. Crit. Rev. Plant Sci. 24, 385, 2005.

43. STOLARSKI M. Agrotechnical and economic aspects of biomass production from willow coppice (Salix spp.) as an energy source. Olsztyn: University of Warmia and Mazury in Olsztyn, 2009 [In Polish].

44. BOEHMEL C., LEWANDOWSKI I., CLAUPEIN W. Comparing annual and perennial energy cropping systems with different management intensities. Agric. Syst. 96, 224, 2008.

45. BÖRJESSON P. Energy analysis of biomass production and transportation. Biomass Bioenerg. 11, 305, 1996.

46. BÖRJESSON P, BERNDES G. The prospects for willow plantations for wastewater treatment in Sweden. Biomass Bioenerg. 30, 428, 2006.

47. LABRECQUE M., TEODORESCU T.I., DAIGLE S. Biomass productivity and wood energy of Salix species after 2 years growth in SRIC fertilised with wastewater sludge. Biomass Bioenerg. 12, 409, 1997.

48. KWAŚNIEWSKI D. Energy efficiency of biomass production from a 3-year-old willow. Inż. Rol. 14, 113, 2010 [In Polish].

49. TUOMISTO H.L., HODGE I.D., RIORDAN P., MACDONALD D.W. Comparing energy balances, greenhouse gas balances and biodiversity impacts of contrasting farming systems with alternative land uses. Agric. Syst. 108, 42, 2012.

50. GOGLIO P., OWENDE P.M.O. A screening LCA of short rotation coppice willow (Salix sp.) feedstock production system for small-scale electricity generation. Biosyst. Eng. 103, 389, 2009.

51. GONZÁLEZ-GARCÍA S., MOLA-YUDEGO B., DIMITRIOU I., ARONSSON P., MURPHY R. Environmental assessment of energy production based on long term commercial willow plantations in Sweden. Sci. Total Environ. 421-422, 210, 2012.

52. AHLGREN S., BAKY A., BERNESSON S., NORDBERG Å., NORÉN O., HANSSON P.A. Future fuel supply systems for organic production based on Fischer-Tropsch diesel and dimethyl ether from on-farm-grown biomass. Biosyst. Eng. 99, 145, 2008

53. PIMENTEL D. Ethanol fuels: Energy balance, economics, and environmental impacts are negative. Nat. Resour. Res. 12, 127, 2003.

54. BOURNE J.K., CLARK M. Biofuels. Natl. Geogr. 10, 36, 2007. 
55. LARSON E.D., FIORESE G., LIU G., WILLIAMS R.H., KREUTZ T.G., CONSONNI S. Co-production of decarbonized synfuels and electricity from coal + biomass with $\mathrm{CO}_{2}$ capture and storage: an Illinois case study. Energy Env. Sci. 3, 28, 2010.

56. GIUNTOLI J., AGOSTINI A., EDWARDS R., MARELLI L. Solid and gaseous bioenergy pathways: input values and GHG emissions. Report EUR 26696 EN. European
Commission, Joint Research Centre. Luxembourg: Publications Office of the European Union, 2014.

57. CENTRAL STATISTICAL OFFICE. Concise statistical yearbook of Poland. Warsaw: Central Statistical Office, 2014.

58. HELLER M.C., KEOLEIAN G.A., MANN M.K., VOLK T.A. Life cycle energy and environmental benefits of generating electricity from willow biomass. Renew. Energ. 29, 1023, 2004. 